\title{
NOTES
}

\section{CIVIL PROCEDURE: NEW JERSEY ADOPTS STANDARDS OF FORUM NON CONVENIENS IN GRANTING IMMUNITY FROM SERVIGE OF PROGESS TO NONRESIDENT LITIGANTS}

$\mathbf{T}$ HE doctrine exempting nonresidents from service of civil process while in the state for the purpose of attending trial has roots in the English common law as early as the reign of Henry VI. ${ }^{1}$ In the United States, most jurisdictions adopted the doctrine with only such modifications as were required to make it harmonize with American institutions and jurisprudence. ${ }^{2}$ However, many exceptions to the basic rule gradually developed, ${ }^{3}$ and in recent years the rule itself has come under attack. ${ }^{4}$ In Wangler $v$. Harvey, ${ }^{5}$ the Supreme Court of New Jersey abandoned its old rule of immunity for nonresident litigants and adopted a more flexible approach to the problem.

The defendant, a resident of New York, was in New Jersey 'to defend a suit instituted against him as executor of his father's estate which was located in New Jersey. ${ }^{6}$. While standing outside the courtroom, the defendant was served with a summons and complaint in the instant action which named him as a defendant in his individual capacity. ${ }^{7}$

142 AM. Jur. Prociess \$ 139, at 120 (1942); 21 R.C.L. Process $\$$ 52, at 1307:08 (1929). See also Hatch v. Blissett, 13 Annae 308, 93 Eng. Rep. 338 (1714).

242 Am. Jur. Process $\$ 139$, at 120 (1942); 21 R.C.L. Process $\$ 52$, at 1307-08 (1929). Sce, e.g., Brooks v. State ex rel. Richards, 26 Del. (3. Boyć) 1, 79 Atl. 790 (1911); Sofge v. Lowe, 131 Tenn. 626, 176 S.W. 106 (1915):

${ }^{3}$ See generally 42 Am. Jur. Process $\$ \$ 139-44$ (1942); 72 C.J.S. Process $\$ 80$ (a).(2) (1951).

'See, e.g., Mertens v. McMahon, 334 Mo. 175, 66 S.W.2d 127 (1933); Keeffe \& Roscia, Immunity and Sentimentality, 32 CoRnell L.Q. 471 (1947). Cf. Velkov v. Superior Court, $40 \mathrm{Cal}$. 2d 289, 253 P.2d 25 (1953); Kirtley v. Chambérlin, 250 Iowa 136, 93 N.W.2d 80 (1958); Eberlin v. Pennsylvania R.R., 402 Pa. 520, 167 A.2d 155 (1961); I BEALE, THE CoNFLICT OF LAwS $\S 78.5$, at 342 (1935); Developinents in the Law-State-Court Jurisdiction, 73 HARv. L. REv. 909, 941 (1960).

41 N.J. 277, 196 A.2d 513 (1963).

- Service of process in the suit had been made upon the Surrogate. Under the requirements of N.J. STAT. ANN. \$ 3A:12-14 (1953), a nonresident executor must file a power of attorney with the Surrogate making him agent for substituted service of process in any action against the estate.

${ }^{7}$ Both actions arose from an accident which allegedly occurred on premises owned by the father at the time of his death and devised to the defendant and another subject 
The trial court granted a motion by the defendant to quash service of process on the ground that as a nonresident he was immune from such service. ${ }^{8}$ The Supreme Court, granting certification on its own motion, reversed and remanded the case for trial. ${ }^{\circ}$

In doing so, the court held that the long-standing rule of immunity was an anachronism, "wholly inconsistent with today's concept of justice."10 Rejecting the old rule, the court adopted a modified approach under which the principles of forum non conveniens govern the granting of immunity to a nonresident litigant served with process within the state. Although nonresident witnesses apparently still have the protection of the old rule, ${ }^{11}$ granting of immunity to nonresident litigants, under the holding in this case, is to be considered an exception rather than standard practice. The moving party shall have the burden of making an affirmative showing of a violation of the traditional concepts of fair play and substantial justice before dismissal will be justified.12

Under the early common law, the privilege of immunity was applicable only to residents of a jurisdiction. ${ }^{13}$ Later it was extended to nonresidents and was finally limited to include only the latter. The majority of jurisdictions in the United States hold that litigants,

to an intermediate life estate. Defendant, in his capacity as executor, had contacted plaintiff, a real estate broker, to arrange for the sale of the land. While defendant was showing the property to plaintiff, the alleged accident occurred. Plaintiff thus sought to hold both the estate and the individual defendant liable for the alleged negligence. 196 A.2d at 513.

${ }^{8}$ Defendant relied on Halsey v. Stewart, 4 N.J.L. 426 (Sup. Ct. 1817), which held that a party to a suit, while necessarily going to, staying at, or returning from the court, is privileged from service of process. Accord, Lamb v. Schmitt, 285 U.S. 222 (1932); Stewart v. Ramsay, 242 U.S. 128 (1916); Dungan v. Miller, 37 N.J.L. 182 (Sup. Ct. 1874); Grober v. Kahn, 76 N.J. Super. 252, 184 A.2d 161 (Ch. Div. 1962); Randall v. Randall, 14 N.J. Super. 110, 81 A.2d 400 (Ch. Div. 1951); Younger v. Younger, 5 N.J. Super. 371, 69 A.2d 219 (App. Div. 1949); Herman v. Arndt, 116 N.J.L. 150, 182 Atl. 830 (Ct. Err. \& App. 1986). Cf. Korff v. G \& G Corp., 21 N.J. 558, 122 A.2d 889 (1956).

- The plaintiff appealed the decision of the Law Division to the Superior Court, Appellate Division. However, that appeal was never argued, for it was immediately certified to the Supreme Court.

10196 A.2d at 516-17.

11 The court noted with approval Baldwin v. Emerson, 16 R.x. 304, 307, 15 Atl. 83, 84 (1888) where it was stated: "While we concede the force of the reasons advanced for protecting non-resident witnesses from the service of a summons against them for the commencement of a suit... we are not convinced of the sufficiency of the reasons assigned for the exemption of non-resident suitors from such process." " 196 A.2d at 516. (Emphasis added.)

12196 A.2d at 518.

${ }^{13}$ In its inception, the exemption was from arrest but was subsequently enlarged to encompass all forms of civil process. 21 R.C.L. Process $\S 52$ (1929). 
whether plaintiffs or defendants, and witnesses in attendance at a court outside the territorial jurisdiction of their residence are immune from service of process while attending court. ${ }^{14}$ The tendency, however, has been to modify this rule with the result that the immunity does not apply to process issued in the very cause for which the person entered the jurisdiction or in another cause which is in aid of, incidental to, or connected with the original suit. ${ }^{15}$ In a minority of jurisdictions, under no circumstances are nonresident litigants entitled to immunity. ${ }^{16}$ Some jurisdictions, combining aspects of both rules, extend immunity to nonresident defendants but withhold it from nonresident plaintiffs. ${ }^{17}$ A few jurisdictions intimate that even the nonresident defendant's immunity is limited to certain circumstances. ${ }^{18}$

Originally, the exemption was a privilege of the courts, but today the benefit of the rule inures to individuals as well.18 The doctrine was developed in order to prevent interruptions and delay in judicial proceedings and to protect witnesses and parties from the temptation to disobey the process of the courts. ${ }^{20}$ In addition, several more specific considerations have been suggested ${ }^{21}$ as foundations of the rule: (1) the necessity of having courts open with protection for all who approach them; ${ }^{22}$ (2) the necessity of the maintenance of the

14 This privilege also extends for a reasonable time while the person is going to or returning from the court. See generally 72 G.J.S. Process $\$ 80$ (a) (2) (1951).

${ }^{15} \mathrm{Ibid}$. See also Employers Mut. Liab. Ins. Co. v. Hitchcock, 158 F. Supp. 783 (E.D. Mo. 1958); Velkov v. Superior Court, 40 Cal. 2d 289, 253 P.2d 25 (1953); Kirtley v. Chamberlin, 250 Iowa 136, 93 N.W.2d 80 (1958); Korff v. G \& G Corp., 21 N.J. 558, 122 A.2d 889 (1956); Grober v. Kahn, 76 N.J. Super. 252, 184 A.2d 161 (Ch. Div. 1962); Mueller v. Eucenham, 33 N.J. Super. 156, 109 A.2d 462 (App. Div. 1954); Eberlin v. Pennsylvania R.R., 402 Pa. 520, 167 A.2d 155 (1961); 74 HARv, L. REv. 627 (1961).

${ }^{10} \mathrm{See}$, e.g., Cannata v. White OwI Express, Inc., 339 Ill. App. 79, 89 N.E.2d 56 (1949); Mertens v. McMahon, 334 Mo. 175,66 S.W.2d 127 (1933).

${ }^{17}$ See, e.g., Adam v. Saenger, 303 U.S. 59 (1938); Tiedemann v. Tiedemann, 35 Nev. 259, 129 Pac. 313 (1913); State ex rel. Spigner v. Superior Court, 175 Okla. 632, 54 P.2d 317 (1936); Livengood v. Ball, 63 Okla. 93, 162 Pac. 768 (1917).

${ }^{18}$ The Tiedemann case, supra note 17 , is an example. See also, Russell v. Landau, 127 Cal. App. 2d 682, 274 P.2d 681 (Dist. Ct. App. 1954); Kirtley v. Chamberlin, 250 Iowa 136, 93 N.W.2d 80 (1958); State ex rel. Spigner v. Superior Court, supra note 17.

10 The rule enables the nonresident to litigate his rights without fear of molestation and enables him to procure the attendance of such witnesses as are necessary for his defense and support. See Velkov v. Superior Court, 40 Cal. 2d 289, 292, 253 P.2d 25, 26 (1953); Halsey v. Stewart, 4 N.J.L. 426, 427 (Sup. Ct. 1817); Netograph Mfg. Co. v. Scrugham, 197 N.Y. 377, 380, 90 N.E. 962,963 (1910).

${ }^{30}$ See cases cited note 19 supra and note 23 infra.

31 See, e.g., Keeffe \& Roscia, supra note 4, at 473.

29 Id. at 474-75. See Stewart v. Ramsay, 242 U.S. 128, 129 (1916), where the Court said: " 'Courts of justice ought everywhere to be open, accessible, free from interrup- 
court's dignity; (3) the prevention of embarrassment and interruption of a court by a litigant's being served with process; and (4) the promotion of the due administration of justice by the encouragement of the voluntary attendance of persons necessary to the exercise of the judicial function. Only the last of these appears to be of continuing importance today. ${ }^{23}$

The Supreme Court of New Jersey considered the doctrine as having outlived its usefulness in that state. ${ }^{24}$ In the first place, the

fion, and to cast a perfect protection around every man who necessarily approaches them. The citizen, in every claim of right which he exhibits, and every defense which he is obliged to make, should be permitted to approach them, not only without sub. jecting himself to evil, but even free from fear of molestation or hindrance. He should also be enabled to procure, without difficulty, the attendance of all such persons as are necessary to manifest his rights." (Quoting from Halsey v. Stewart, 4 N.J.L. 426, 427 (Sup. Ct. 1817)).

- ${ }^{28}$ Lamb v. Schmitt, 285 U.S. 222, 225 (1932). This consideration seems aimed primarily at the protection of witnesses. See Halsey v. Stewart, supra note 22, at 368-69.

The immunity rule developed at a time when physical arrest was part of the procedure of service of process: "The arrest of a party to a suit... being regarded as $a$ breach of the defendant's privilege, the usual course was to appear in the cause in which the arrest was made, and procure a rule against tbe plaintiff and his attorney to show cause why the defendant should not be discharged out of custody by reason of his alleged privilcge...'" Greer v. Young, 120 Ill. 184, 188, 11 N.E. 167, 168 (1887).

It has been said that: "The concept that the due administration of justice will be impeded unless the necessary persons are in attendance is the sound basis upon which the immunity doctrine arose. Where the exigencies of the judicial machinery are such that the presence of certain persons otherwise unobtainable is needed the granting of privileges to secure their attendance is a logical and necessary function.

"Thus, it is everywhere recognized that witnesses from other jurisdictions are immune from service of process. ... If they do not come voluntarily, their presence cannot be compelled; hence immunity from. suit is granted them." Keefe \&: Roscia, supra note 4 , at 477-78.

2* There is no constitutional right of immunity from service of process. Application of Waterfront Comm'n of New York Harbor, 39 N.J. Super. 33, 120 A.2d 504 (L. 1956). Indeed, it is a privilege extended by the courts to meet certain of their needs. Long v. Ansell, 293 U.S. 76, 83 (1934); Page Co. v. MacDonald, 261 U.S. 446, 448 (1923). In recent years some jurisdictions have tended to confuse the privilege with some substantive right of the individual. In Murrey v. Murrey, $216 \mathrm{Cal} .707,710,16$ P.2d 741, 742 (1932), the court said: "Originally this privilege of exemption from service was deemed a privilege of the court and not a privilege of the individual. In more recent years, it has come to be recognized as a substantive right of the individual. It has been frequently stated that this 'judicial' privilege exists as a matter of cstablished public policy and rests upon sound principles of justice and right." In a note, 5 CALIF. L. REv. 347 (1917), the writer said: "The privilege finds its basis in the very substantive right of every man to be sued at home, a right which he is not willing to risk by voluntarily entering another jurisdiction even to attend court."

More than one court has warned that the rule should not be extended beyond the reason upon which it is founded but should be extended or withheld only as judicial necessities require as determined within the discretion of the state. Lamb v. Schmitt, supra note 23. See also Netograph Mfg. Co. v. Scrugham, 197 N.Y. 377, 380, 90 N.E. $962,963 \cdot(1910)$. 
court apparently felt that there is no justification for the rule's discrimination in favor of nonresident litigants. ${ }^{25}$ They pointed out that there is no longer any danger of interruption of the court by service of process upon a litigant, for physical restraint has ceased to constitute an element of that procedure. ${ }^{26}$ Similarly, a litigant will seldom, if ever, be distracted by service of process in a related, or even collateral, action. ${ }^{27}$ The court recognized that there is still some validity to the rule insofar as it encourages the voluntary attendance of litigants ${ }^{28}$ but held that this alone is not sufficient to compel the retention of the otherwise unsatisfactory doctrine. ${ }^{2 \theta}$

An unarticulated, but apparent, reason for the widespread acceptance of the immunity doctrine is that in some circumstances, for policy reasons, a court may not wish to exercise its jurisdiction in all cases. ${ }^{30}$ However, the inflexibility of the old rule renders it unsatisfactory, in that it allows the court no discretion in cases in which the protection of the state's interests demand retention of jurisdiction. Accordingly, the court found a much more-satisfactory approach to the problem of nonresident litigant immunity by applying the more plastic principles of forum non conveniens.

Simply stated, the principle of forum non conveniens is that a court may resist imposition upon its jurisdiction even when the jurisdiction is clearly authorized. ${ }^{31}$ The doctrine presupposes at

25 "The principle of immunity allows a nonresident to defend suits in our Statewithout subjecting himself to another suit, while it prevents a resident defendant from claiming such protection. Historically, both categories of defendants would be protected, but today the resident defendant is not." 196 A.2d at 516-17.

${ }^{20}$ See note 23 supra.

27196 A.2d at 517 .

28 "The most persuasive argument for the immunity rule is that the privilege is granted to encourage attendance of litigants whose appearances are necessary to the trial of the cause.... It is argued that unless immunity is granted to a litigant, he might be deterred from attending through fear of being subjected to new litigation. Thus, the court's search for truth might be frustrated and an injustice might result." 196 A.2d at 517. See note 22 supra.

${ }^{20}$ The court said that the granting of immunity actually conflicts with other important policy considerations: it denies the right of a creditor to sue his debtor wherever he may be found; and it shifts the burden of traveling to a foreign jurisdiction from the nonresident to the resident party. $196 \mathrm{~A} .2 \mathrm{~d}$ at 517.

${ }^{30}$ See Gulf Oil Corp. v. Gilbert, 330 U.S. 501, 507 (1947); Annot., 85 A.L.R. 1340 (1933); Developments in the Law-State-Court Jurisdiction, supra note 4, at 1012.

${ }^{31}$ See generally Gulf Oil Corp. v. Gilbert, supra note 30; Barrett, The Doctrine of Forum Non Conveniens, 35 GALIF. L. REv. 380 (1947); Blair, The Doctrine of Forum Non Conveniens in Anglo-American Law, 29 Colum. L. Rev. 1 (1929); Braucher, The Inconvenient Federal Forum, 60 HARv. L. REv. 908, 911-18 (1947); Developments in the Law-State-Court Jurisdiction, supra note 4, at 1008-15. The doctrine has largely been superseded in federal courts by the 1948 adoption of 28 U.S.C. $\S 1404$ (a). WRłGHT, FEDERAL CourTs $§ 44$, at 141 (1963). 
least two forums in which the defendant is amenable to suit ${ }^{82}$ and provides criteria for a choice between them. The application of the doctrine is left to the discretion of the trial judge who must balance private and public interests to determine the relative advantages and obstacles to a fair trial within the jurisdiction. ${ }^{\mathbf{3 3}}$

The doctrine of forum non conveniens is well established in New Jersey. The courts have emphasized that it is not enough that a defendant will be inconvenienced by a trial within the state; it must also appear that a dismissal will not result in a significant hardship for the plaintiff. ${ }^{34}$ Dismissal will be granted only where a weighing of all the relevant factors decisively established that there is available another forum where trial will be more convenient for the parties and the ends of justice will better be served. ${ }^{35}$

s2 Gulf Oil Corp. v. Gilbert, 330 U.S. 501, 507-08. The forums which the doctrine presupposes may well be theoretical rather than actual. For example, if a clefendant domiciled in New York is served with process in North Carolina, he is considered amenable to suit in New York, even though the New York statute of limitations actually may bar an action against him.

${ }^{33}$ Among the private interests to be considered are: (1) relative ease of access to sources of proof; (2) availability of compulsory process for the attendance of unvilling, and the cost of obtaining the attendance of willing, witnesses; (3) possibility of a view of the premises, if such view would be appropriate to the action; and (4) residence of the parties. Among the factors of public interest are: (1) the administrative burden which the case would impose upon the court; (2) the desirnbility of baving purely local affairs tried in the place where they arose; and (3) the desirability of holding the trial at the place whose local law will govern the merits of the case. Gulf Oil Corp. v. Gilbert, supra note 32, at 508-09. No one of these factors is conclusive, for in most instances it will be necessary to decide upon the facts and circumstances of the particular case at issue. Annot., 48 A.L.R.2d 800, 819 (1956). But it is generally held that unless the balance is strongly in favor of the defendant, the plaintiff's choice of forum must not be disturbed. Gulf Oil Corp. v. Gilbert, supra; Houston Fearless Corp. v. Teter, 318 F.2d 822, 827-28 (10th Gir. 1963); Menendez Rodriguez v. Pan Am. Life Ins. Co., 311 F.2d 429, 432 (5th Cir. 1962).

34 Starr v. Berry, 25 N.J. 573, 587, 138 A.2d 44, 51 (1958). The court pointed out that a plaintiff's choice should not be denied on a mere weighing of conveniences. It said the controlling test must be practicality as well as inherent justice.

Domestic residence is not decisive in the retention of jurisdiction. While it is true that an action by a resident will ordinarily not be dismissed on the ground of inconvenience, the court will treat an action between two nonresident parties on the same basis-whether justice can be done as well in New Jersey as in some other forum. Gore v. United States Steel Corp., 15 N.J. 301, 104 A.2d 670 (1954).

${ }^{35}$ Gore v. United States Steel Corp., supra note 34, at 311, 104 A.2d at 675-76.

In Vargas v. A. H. Bull S.S. Co., 25 N.J. 293, 295, 135 A.2d 857, 858 (1957), the court said: "Even where all of the relevant considerations of convenience in the juristic sense point to the conclusion that an action should not be entertained in the forum where it was instituted, collateral equities may exist in a plaintiff's favor which should not be ignored although they may not be of sufficient potency to stand in the way of the dismissal. In such situations the exercise of discretion may and properly should take these factors into account by the simple device of making the dismissal subject to appropriate terms and conditions and thus accomplishing equal justice between the parties." 
The result reached in this case puts nonresident litigants, in the state only for the purpose of attending trial, on an equal basis with any other nonresident who is served with process within the state. The approach is a means by which a state is better able to protect its own interests. Clearly the state owes a duty to its citizens to protect their interests, and the rule which does not permit an exercise of discretion by the court in the particular case presented serves only to frustrate that duty. Under the Wangler approach, however, a court may examine the state's interest in a case before a ruling is made on the motion to dismiss. If the court finds a state interest which legitimately may be asserted, then jurisdiction may be retained. Conversely, if the interest of the state is miniscule, whereas retention of jurisdiction would work undue hardship on the nonresident, the court may dismiss. From the point of view of the state, this is considerably more advantageous than a rule which arbitrarily granted automatic immunity to certain groups before its courts.

Although it is clear that generally the approach adopted by the court is advantageous to the state, the court chose a less than satisfactory manner in which to announce the new policy. The situation presented in the Wangler case appears to be one which called for a prospective rather than a retrospective holding; it seems harsh to subject a fiduciary to suit in his individual capacity after he had entered the state thinking he would be immune. ${ }^{36}$ In any event, it would be of significant benefit to the state to limit the new rule so as to prevent its application to nonresident fiduciaries who are required to enter the jurisdiction to defend suits against the estates which they represent. ${ }^{37}$ The more efficient administration of estates

\footnotetext{
${ }^{30}$ On this point, the court split. The concurring opinion said that since the present action arose out of the original suit for which the defendant entered the state, service of process was valid under an exception to the immunity rule. 196 A.2d at 519.

The dissent said that the legal distinction between the executor in his representative capacity and in his individual capacity presented equitable considerations sufficient to prevent service upon one to be valid as against the other. $196 \mathrm{A.2d}$ at 520 .

A.2d at 520 .

It is suggested that the court could have decided this case on either of the above rationales and was not compelled to abandon the old immunity rule so abruptly.

${ }^{37}$ It would constitute a breach of his fiduciary duty for an executor to allow a default judgment against the estate. Atkinson, WiLss $\S 117$ (2d ed. 1953). Thus he is not free to decide whether to enter the state to defend a suit against the estate which he represents.

If immunity is abandoned, fiduciaries who are liable for collateral actions in the jurisdictions containing the estates which they represent may resign in order to avoid
} 
which would result would seem to be well worth the limited sacrifice of discretion required of the court.

risking a suit against them personally. A new executor would have to qualify and be appointed. This might develop into a chain reaction if the second were to become liable and subsequently resign. The instability in the administration of estates which might possibly result certainly would not be in the best interests of the state. 